Review

\title{
Water-Energy-Food Nexus: Critical Review, Practical Applications, and Prospects for Future Research
}

\author{
Aries Purwanto $^{1, *}$, Janez Sušnik ${ }^{1} \mathbb{D}$, Franciscus X. Suryadi ${ }^{1}$ and Charlotte de Fraiture ${ }^{1,2}$ \\ 1 Land and Water Management Department, IHE-Delft Institute for Water Education, \\ 2601 DA Delft, The Netherlands; j.susnik@un-ihe.org (J.S.); f.suryadi@un-ihe.org (F.X.S.); \\ c.defraiture@un-ihe.org (C.d.F.) \\ 2 Department of Environmental Sciences, Water Resources Management, Wageningen University and Research, \\ 6708 PB Wageningen, The Netherlands \\ * Correspondence: a.purwanto@un-ihe.org
}

Citation: Purwanto, A.; Sušnik, J.; Suryadi, F.X.; de Fraiture, C. WaterEnergy-Food Nexus: Critical Review, Practical Applications, and Prospects for Future Research. Sustainability 2021, 13, 1919. https://doi.org/ $10.3390 /$ su13041919

Academic Editor: Stephen Morse

Received: 15 January 2021

Accepted: 4 February 2021

Published: 10 February 2021

Publisher's Note: MDPI stays neutral with regard to jurisdictional claims in published maps and institutional affiliations.

Copyright: (c) 2021 by the authors. Licensee MDPI, Basel, Switzerland. This article is an open access article distributed under the terms and conditions of the Creative Commons Attribution (CC BY) license (https:// creativecommons.org/licenses/by/ $4.0 /)$.

\begin{abstract}
This paper presents knowledge gaps and critiques on the water-energy-food (WEF) nexus that have emerged since the concept of the WEF nexus was proposed by the World Economic Forum and the Bonn 2011 Conference. Furthermore, this study analyses current innovations on the WEF nexus concept, applications, and impacts during the period of 2012-2020. This begins by reviewing ten WEF nexus frameworks developed by international organizations and researchers. On this basis, several gaps and omissions in nexus frameworks are obvious in almost all developed frameworks. Studies that start to address some of these gaps are analysed, but they are relatively few and do not address all gaps. Several proposed improvements to nexus frameworks are identified to narrow the gaps and put the concept into practical implementation in WEF resources management and governance. Four principles and the perspective of "from local to global" for future WEF nexus framework development and analysis are suggested to ensure that the security of water, energy, and food resources can be achieved sustainably in local communities. This will improve the impact of national and global ambitions on WEF security.
\end{abstract}

Keywords: water-energy-food (WEF); nexus concept; knowledge gaps; critiques; WEF security

\section{Introduction}

The connections between the water, energy, and food (WEF) sectors, known as the WEF nexus, are becoming a major academic, policy, and societal topic that is increasingly discussed in global society, including the relationship with ecosystems, livelihoods, and the economy (e.g., [1-3]). The challenges to managing water, energy, and food resources simultaneously and meet multiple potentially conflicting objectives without compromising the resource base of any sector are urgent and need to be resolved as best as possible (i.e., causing the least amount of damage to other sectors). This challenge demands an integrated approach in which the systems are considered as a whole. To add to the complexity, the WEF nexus influences and is influenced by other sectors including economic, social, political, and environmental conditions $[4,5]$. The basic concept of the WEF security nexus approach was developed and extensively discussed in the Bonn 2011 Nexus Conference. In the resulting background paper, the nexus approach is defined as "an approach that integrates management and governance across sectors and scales" [6]. The integration of theoretical approaches and practical implementation to solving policy challenges is urgently needed.

In Hoff's background paper [6], initial guidance on how a nexus approach can improve the security of WEF resources by increasing efficiency, reducing trade-offs, building synergies and improving governance across sectors, including several policy recommendations, was introduced. Since then, comprehensive studies and critical reviews by Endo et al. [7] and Albrecht et al. [8] state that the background paper by Holger Hoff and the 
World Economic Forum meeting in 2011 [9] has brought the topic and concept of the WEF nexus to the centre of global attention. However, several gaps were identified in nexus approach frameworks and subsequent nexus studies.

This paper has several objectives. The first is to review existing WEF nexus frameworks, showing where they overlap and considering key areas omitted from most if not all of these frameworks. The second step is to revisit several key WEF nexus critiques with the aim of identifying knowledge, research, and application gaps from those studies. These gaps are then mapped onto those from the nexus frameworks. These steps allow identification of the most urgent outstanding issues in current nexus research. Following this, several applied WEF nexus case studies are discussed, illustrating the extent to which the identified gaps and omissions have been addressed (or started to be addressed). From this, research gaps that are still present in nexus research are highlighted as urgent avenues for future research. The steps applied in this paper are outlined in Figure 1. These steps are reflected in the structure of this paper.

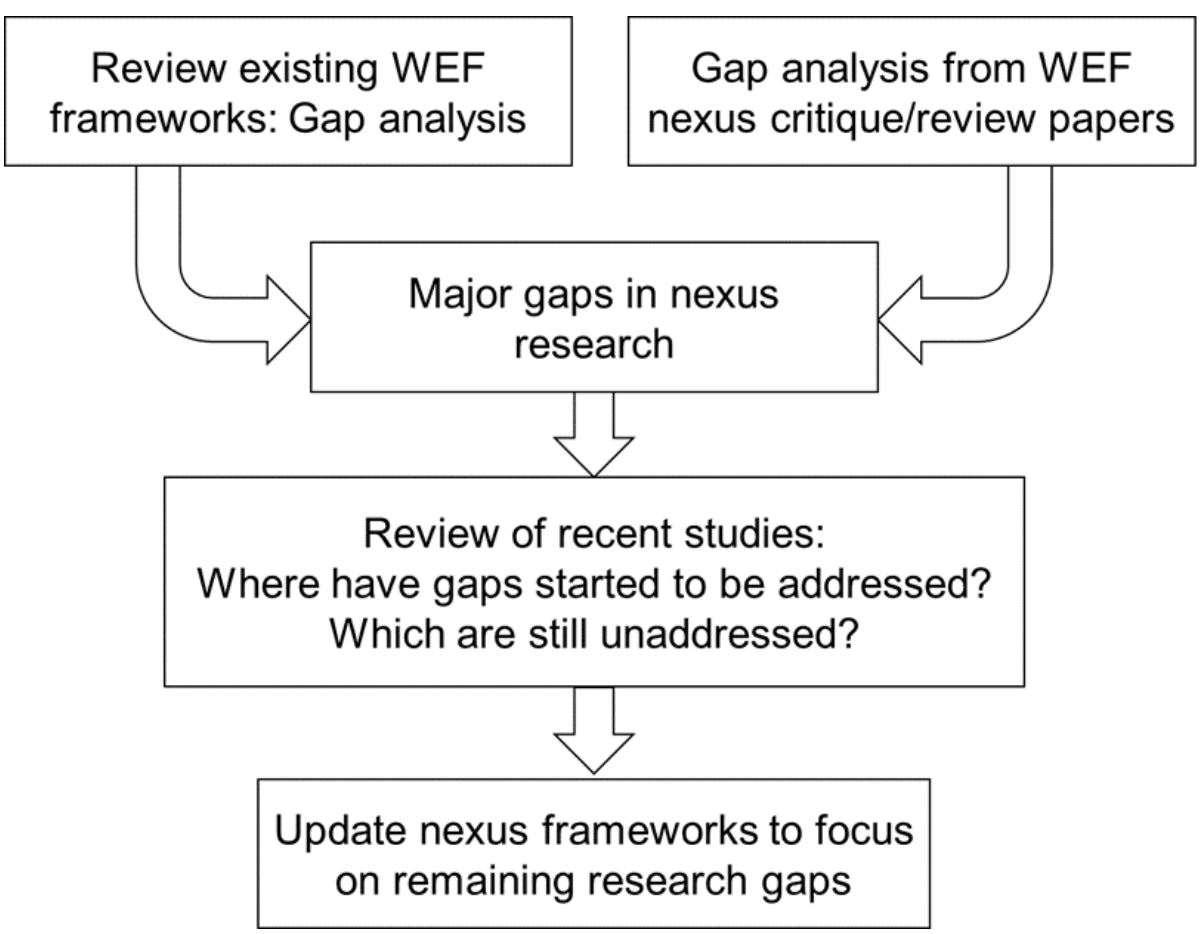

Figure 1. Schematic flow chart of the process followed in this paper.

\section{Assessing Existing WEF Nexus Frameworks}

Existing WEF nexus frameworks were selected following a literature review of frameworks published in academic and non-academic sources using Google Scholar (cf. [10]), Science Direct, and Scopus databases. The databases were used to identify peer-reviewed scientific documents and other publications that employed the WEF nexus concept during the period 2012-2020. Further investigation was conducted to clarify the main concerns, key principles, and variables of the frameworks. While not meant as comprehensive, the results are representative of commonly presented WEF nexus frameworks in the literature, and much overlap can be identified between the frameworks discussed in this section.

While the concept of interlinkages and integration between the WEF sectors is not new (it has been understood by local communities and private sectors for some time (e.g., [7,10-12])), it is arguable that the modern concept of the WEF nexus became mainstreamed after 2011 when the World Economic Forum published a report which was the result of numerous analyses and studies [9]. In the Global Risks 2011 (sixth edition) report, the interconnectedness between water, energy and food sectors with other external variables such as economic and population growth, environmental pressures, global gover- 
nance failures, and even geopolitics conflict was postulated. This report identified some direct and indirect impacts that may arise due to risks associated with these interlinkages, including major trends and uncertainties, levers, and trade-offs [9]. Several key issues were identified. These include recognizing trade-offs, integrated and multi-stakeholder planning, community-level empowerment, market-led pricing, and technological and financial innovations to improve WEF management at any level.

After the publication of the 2011 Global Risks report, the next influential event was the Bonn 2011 Conference on the water, energy, and food security nexus that was held on 16-18 November 2011. The background paper from the conference entitled "Understanding the Nexus", has become an influential reference in research related to the WEF nexus approach [6]. Figure 2 shows the WEF nexus framework, describing the complexity of the WEF nexus with water availability as the core of the system. It considers the importance of sustainable development actions, global trends, and governmental interventions. Several key principles among others include resource productivity, the concept of waste as a resource, economic incentives, and coherence in governance, institutions, and policies.

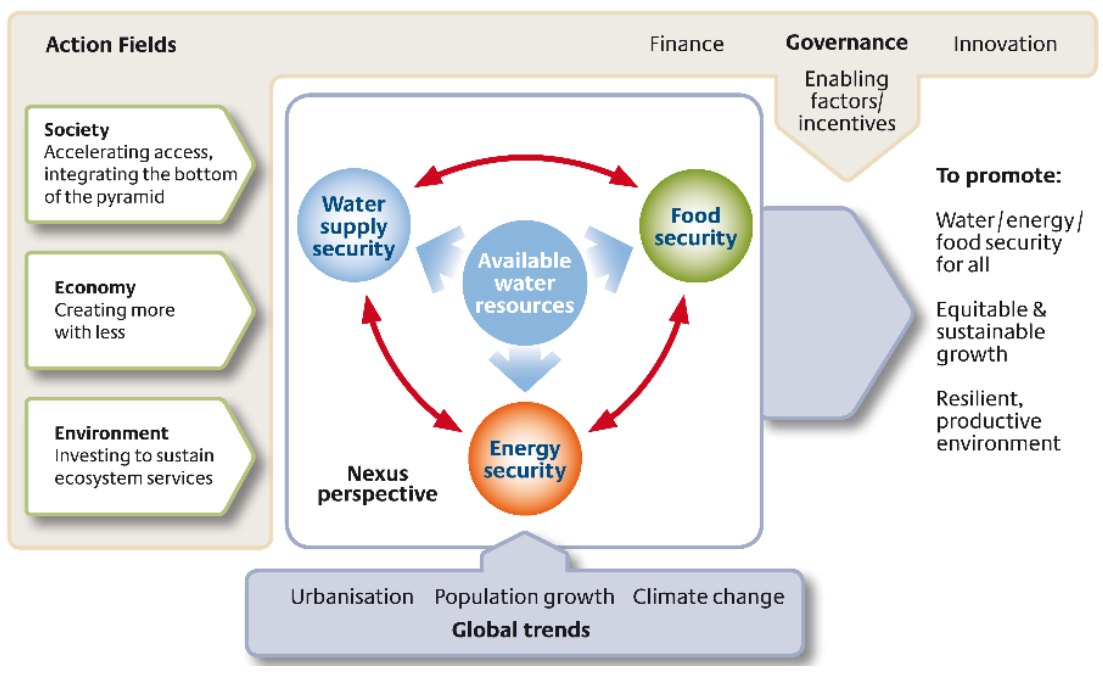

Figure 2. The water-energy-food nexus framework (source: Hoff [6]. Reprinted with permission from the author).

The Hoff background paper proposed some knowledge gaps in the nexus approach that were suggested to be addressed. As the background paper is well known in the nexus research community, Hoff's knowledge gaps can become the focus of researchers in order to address the gaps and improve nexus understanding.

Many WEF frameworks, tools, and models have been developed since the Bonn 2011 Conference. Several innovations and modifications of the "original" WEF nexus framework have been developed by various international organizations, research institutes, and researchers. The association between WEF sectors and external variables, which is in line with the sustainable development concept, has been illustrated in various frameworks, some of which are summarized in Table 1.

The frameworks (Table 1) have been used as a reference at many levels of governance (e.g., global, national, and regional) and spatial scales (e.g., basin-scale and household-scale) of management and planning. Because of their generic nature, many cannot be applied directly, with local-level modifications needed to capture specific circumstances. There is a need to make such comprehensive elaboration and adjustment by following the principles of context-specific and stakeholder engagement to address the challenges and to make them more applicable to assist local level policy-makers and other stakeholders. 
Table 1. A selection of representative WEF nexus frameworks and their main features.

\begin{tabular}{|c|c|c|}
\hline & WEF Nexus Framework & Document Source and Publisher \\
\hline A & $\begin{array}{l}\text { Food, Water, and Energy Nexus and the Contribution ofHimalayan } \\
\text { Ecosystem Services [13] } \\
\text { - The core of the framework is ecosystem goods and services to support } \\
\text { WEF sectors and implemented in South Asia } \\
\text { - Key principles: (1) water storage capacity restoration, (2) climate and } \\
\text { environmentally and social-friendly infrastructure development, } \\
\text { (3) adequate investment for management, (4) incentive mechanism in } \\
\text { managing ecosystem }\end{array}$ & $\begin{array}{l}\text { - Contribution of Himalayan ecosystems to } \\
\text { water, energy and food security in South } \\
\text { Asia: a nexus approach (Figure 2, page 4, } \\
\text { in this document source) } \\
\text { - The International Centre for Integrated } \\
\text { Mountain Development/ ICIMOD } 2012\end{array}$ \\
\hline
\end{tabular}

The Water-Energy-Land (WEL) Nexus [14]

- This framework widens the perspective of the nexus by considering land-use competition for agriculture, forests, human settlement and infrastructure, and biodiversity, including the competition in

B water demands

- Key principles: (1) rethinking the natural resources approach; (2) transformative action in addressing the demand, supply, efficiency, and resilience of natural resource; (3) integrated solution for appropriate management of WEL

The Resource Nexus [15]

- This resource nexus framework focuses on five essential resources: water, energy, minerals, food, and land.

- Key principles: (1) doubling resource efficiency, (2) transition toward sustainable energy systems, (3) coordinating efforts to properly price resources, (4) rethinking of "the good life" and economic growth based on ever-increasing resource consumption, (5) working together to resolve disputes, (6) reinvesting in global leadership

\section{The CLEWS Framework [16]}

- The framework integrates the assessment of three sectors of land, energy, and water resources using several tools i.e., LEAP by SEI, WEAP by SEI,

D and AEZ by IIASA and FAO models with climate change scenarios.

- Key principles: (1) points identification at which the resource systems interact, (2) establish appropriate data exchanges between the modules, (3) process repetition through a series of iterations
- Confronting scarcity: Managing water, energy and land for inclusive and sustainable growth (Figure 2.2, page 27, in this document source)

- European Union 2012

\section{Nexus Dialogue: Agreed Key Interlinkages [17]}

- The centre of the framework is ecosystems and climate and environment as external factors

E - Key principles: (1) policy solutions (2) land use management, (3) cooperation agreements (4) technology, operation and infrastructure, (5) coordination and communication (6) economic instruments (market-based or regulatory)

The Framework Linking Water, Food, Energy Security [4]

- Ecosystem management as the core of the framework

- Recommended policies: (1) integrated approach to policy design, (2) land and agricultural investment, (3) adaptive management of opportunities and risks

- Stages: (1) assessing WEF security system, (2) envisioning future landscape, (3) investing in a WEF security, (4) transforming the system
- The global resource nexus: The struggles for land, energy, food, water, and minerals (Figure 1, page 7, in this document source)

- The Transatlantic Academy (2012)

- Integrated analysis of climate change, land-use, energy and water strategies (Figure 1, page 622, in this document source).

- Macmillan Publishers (www.nature.com/natureclimatechange; accessed on 2 December 2020); KTH-Royal Institute of Technology

- Reconciling resource uses in transboundary basins: assessment of the water-food-energy-ecosystems nexus (Figure 5, page 22, in this document source)

- The United Nations Economic Commission for Europe

- The Water-Energy-Food Security Nexus: Towards a practical planning and decision-support framework for landscape investment and risk management (Figure 6, page 15 , in this document source)

- The International Institute for Sustainable Development/IISD (2013)

\section{Approach to the Water-Energy-Food Nexus [18]}

- This framework describes the complex interaction between human activities and natural resources with four main components; (1) goals and interests, (2) resource base, (3) managing the nexus, and (4) drivers e.g., G population, governance, climate change etc.

- Key principles: (1) provide a stepwise process to address policy-making and intervention in a nexus way, (2) combine quantitative and qualitative assessment methods, (3) proposed indicators are based on available datasets, (4) link intervention assessment to context status
- Walking the nexus talk: Assessing the Water-Energy-Food Nexus in the Context of the Sustainable Energy for All Initiative (Figure 1, page 13, in this document source)

- The Food \& Agriculture Organization (FAO) (2014) 
Table 1. Cont.

\section{WEF Nexus Framework}

Document Source and Publisher

\section{Key Interactions Between Water, Energy, Food Security [19]}

- This framework identifies interaction between WEF security components within the existing national development planning with water security as the core system supported by forest as the main concern

H

- Key principles: (1) trade-offs between agricultural production and biofuel crops and deforestation (2) forest restoration and watershed protection, (3) interaction among four targets of WEF and forest in national development planning

Water, Land, Energy, Food, and Climate (WLEFC) Nexus [20]

- A systematic framework of scientific investigation, design of coherent policy goals, and instruments to deal with synergies, conflicts, and related trade-offs from the interactions between WLEFC at bio-physical, socio-economic, and governance level.

- Key principles: (1) policy coherence, (2) resource efficiency, (3) cross-sectoral governance, (4) interdisciplinary knowledge generation, (5) equal weight of each sector
- How can Indonesia achieve security without eroding water, energy, and food as its natural capital? (Figure 4, page 15, in this document source)

- WCS Indonesia in partnership with the Global Canopy Programme (2016)

Main Linkages Within the Land, Water, and Energy Nexus [21]

- The framework indicates how the biophysical resources are interrelated to economic activities and a number of key policy objectives. It also considers the influence of socio-economic, climate change, and policies to the trade-offs and synergies in LWE nexus

- Key principles: 1st domain (LWE resources) represent biophysical system in term of quantity and quality, 2nd domain resources (goods and services) that meet the needs of the population, e.g., agriculture, energy transformation, and water supply, 3rd domain highlight the resources nexus

- D1.5: Framework for the assessment of the nexus (Figure 5, page 27, in this document source)

- Sustainable Integrated Management FOR the NEXUS of WLEFC for a resource-efficient Europe (SIM4NEXUS) (2016-2020)

Almost all the frameworks indicate that external factors need to be considered in managing WEF resources in an integrated manner. These can include climate change, population, and socio-economic development. The main differences between the frameworks include the key principles with regard to the main concern of each organization (e.g., water resources, food production, and stakeholder dialogue), the scales of each framework, and exogenous factors that influence and are deemed to be influenced by the WEF nexus. Some frameworks propose economic, social, and environmental issues as major components to be considered in managing resources. The Wildlife Conservation Society (WCS) Indonesia in partnership with the Global Canopy Programme (2016), for instance, focuses on forests as their main target. Those frameworks that have followed context-specific principles are arguably going against a true nexus framework, where no resource should take "centre stage". Some frameworks do not comprehensively capture all interactions between variables in the WEF nexus due to availability and limited access of data [22], inadequate consideration of politics in WEF resources management [23], under-representing gender perspectives [24], or ignoring livelihoods and development [25].

The main issues covered by the frameworks in Table 1 are summarized in Table 2. Ten WEF nexus-based frameworks have been analysed and compared with 16 suggested features for the nexus concept. We have found that three out of 10 frameworks have good coverage (over half) of the 16 suggested features. The remaining seven cover up to half of the suggested features, implying they are less comprehensive or are more focused in their coverage. 
Table 2. The evaluation of selected WEF nexus frameworks. ' $V$ ' indicates which frameworks cover which main nexus features.

\begin{tabular}{|c|c|c|c|c|c|c|c|c|c|c|c|}
\hline \multirow{2}{*}{ No. } & \multirow{2}{*}{ Main Features in the Nexus Approach/Framework } & \multicolumn{10}{|c|}{ WEF Nexus Frameworks (Table 1) } \\
\hline & & A & B & $\mathrm{C}$ & $\mathbf{D}$ & $\mathbf{E}$ & $\mathbf{F}$ & G & $\mathbf{H}$ & $\mathbf{I}$ & $\mathbf{J}$ \\
\hline 1. & Incorporate WEF and exogenous variables, multi-resource $[6,22,26]$ & $\mathrm{V}$ & V & $\mathrm{V}$ & $\mathrm{V}$ & $\mathrm{V}$ & $\mathrm{V}$ & $\mathrm{V}$ & $\mathrm{V}$ & $\mathrm{V}$ & $\mathrm{V}$ \\
\hline 2. & Social, economic, and political context $[8,22,27,28]$ & & $\mathrm{V}$ & $\mathrm{V}$ & $\mathrm{V}$ & $\mathrm{V}$ & $\mathrm{V}$ & $\mathrm{V}$ & $\mathrm{V}$ & $\mathrm{V}$ & $\mathrm{V}$ \\
\hline 3. & Green economy, sustainability, environmental context $[6,27]$ & $\mathrm{V}$ & & & $\mathrm{V}$ & $\mathrm{V}$ & $\mathrm{V}$ & $\mathrm{V}$ & $\mathrm{V}$ & $\mathrm{V}$ & $\mathrm{V}$ \\
\hline 4. & Interdisciplinary and transdisciplinary $[7,22,28,29]$ & $\mathrm{V}$ & $\mathrm{V}$ & & $\mathrm{V}$ & $\mathrm{V}$ & $\mathrm{V}$ & $\mathrm{V}$ & & $\mathrm{V}$ & $\mathrm{V}$ \\
\hline 5. & Decision-making, policy-making, governance, solution-oriented $[8,26,30,31]$ & $\mathrm{V}$ & $\mathrm{V}$ & $\mathrm{V}$ & $\mathrm{V}$ & & $\mathrm{V}$ & $\mathrm{V}$ & & $\mathrm{V}$ & $\mathrm{V}$ \\
\hline 6. & Incorporate global trends [6] & & $\mathrm{V}$ & $\mathrm{V}$ & $\mathrm{V}$ & $\mathrm{V}$ & $\mathrm{V}$ & $\mathrm{V}$ & & $\mathrm{V}$ & $\mathrm{V}$ \\
\hline 7. & Case study, local coverage, context specific, in-site context $[6,22,26,27]$ & $\mathrm{V}$ & & & $\mathrm{V}$ & $\mathrm{V}$ & & $\mathrm{V}$ & $\mathrm{V}$ & $\mathrm{V}$ & \\
\hline 8. & Capacity building, awareness raising $[6,26]$ & & & & & $\mathrm{V}$ & $\mathrm{V}$ & $\mathrm{V}$ & $\mathrm{V}$ & $\mathrm{V}$ & \\
\hline 9. & Spatial-temporal scope $[22,26]$ & $\mathrm{V}$ & & & $\mathrm{V}$ & & & $\mathrm{V}$ & & $\mathrm{V}$ & \\
\hline 10. & Practical guide for implementation and simulation $[8,31]$ & & & & $\mathrm{V}$ & $\mathrm{V}$ & & $\mathrm{V}$ & & $\mathrm{V}$ & \\
\hline 11. & Mixed methods of qualitative--quantitative $[22,29]$ & & & & $\mathrm{V}$ & & $\mathrm{V}$ & $\mathrm{V}$ & & $\mathrm{V}$ & \\
\hline 12. & Collaborative, participatory approach, stakeholders involvement $[8,27,28]$ & & & & & $\mathrm{V}$ & $\mathrm{V}$ & $\mathrm{V}$ & & $\mathrm{V}$ & \\
\hline 13. & Robust data sets, minimized data requirement $[22,26,27]$ & $\mathrm{V}$ & & & $\mathrm{V}$ & & & $\mathrm{V}$ & & $\mathrm{V}$ & \\
\hline 14. & Promote innovation, knowledge mobilization, theoretical approach $[8,27,28]$ & & & & $\mathrm{V}$ & & & $\mathrm{V}$ & & $\mathrm{V}$ & \\
\hline 15. & Focuses on WEF resource security [6] & $\mathrm{V}$ & & & & & $\mathrm{V}$ & & $\mathrm{V}$ & & \\
\hline 16. & Appropriate and validated stages, using system approach and critical analysis $[26,28]$ & & & & $\mathrm{V}$ & & & $\mathrm{V}$ & & $\mathrm{V}$ & \\
\hline
\end{tabular}

Based on Table 2, most existing frameworks include overlapping features. The efforts to bring the nexus concept into the process of policy and decision-making can also be seen in some frameworks.

Several features are distinctly lacking. These include:

(1) a focus on WEF resource security (i.e., availability, accessibility, quality of resources);

(2) appropriate and validated stages (cf. [26]) of the WEF nexus modelling process, using a systems approach and critical analysis to better understand nexus complexity [27];

(3) promotion of innovation and knowledge mobilization;

(4) utilization of robust datasets from multiple sources; and

(5) participatory stakeholder involvement in framework development.

\section{Literature Criticisms on the WEF Nexus Concept}

The WEF nexus concept has received criticism. The criticisms largely centre on the apparent lack of focus in nexus studies, the argument that the approach is not "new" per-se, the lack of integration of some sectors (e.g., ecosystems), and the lack of common approaches to studying nexus problems.

Regarding the concept, many researchers argue that the nexus is still an expanding concept [32], is relatively immature [33], is narrative but not useful in applications [34], and is without any common definitions, methods, and frameworks $[5,8,11,35]$. Furthermore, the application of the nexus concept has received much attention from various scholars. For example, Wichelns [33] and Mitchell et al. [36] warned that policy-making processes by applying the nexus approach and involving many stakeholders, especially in developing countries, may lead to delays, slowness, and inertia. However, the involvement of stakeholders is deemed essential for proper nexus mapping and understanding. In addition, existing nexus implementations failed to address complex interlinkages due to a lack of boundary definition [37] and lack of data sharing and availability [22]. Critiques have been raised against the expected outcome in applying the nexus concept in various places around the world. Among the criticisms are the inability to consider inherent political factors [23], the main democratic goal of sustainability [25], gender aspects, and integration of programs, policies, and institutions at the national level [24], as well as the operationalization of WEF nexus in the decision-making process [38]. These issues are summarised in Table 3. 
Table 3. Critiques on the concept, application, and implication of the WEF nexus.

\begin{tabular}{|c|c|}
\hline No. & Main Criticism \\
\hline A. & $\begin{array}{l}\text { The WEF Nexus Concept } \\
\text { 1. It is not really a new [11] and/or novel [12] particularly in low-level application or } \\
\text { users such as farmers, fishers, etc. [7,29]. } \\
\text { 2. Sometimes seen as a "nirvana" and narrative concept [34], "mercurial" concept that } \\
\text { led to unpredictable changes in issues based on the context, location, and scale [12] } \\
\text { without a means to address the challenges. } \\
\text { 3. Only "reframing resource scarcity as an existential threat" and "cling to a neoliberal } \\
\text { economic agenda" [39]. } \\
\text { 4. It is not a clearly defined construct or an agreed-upon and tested framework [33], not } \\
\text { a mature concept and needs further improvement [40]. It is promising but still faces } \\
\text { significant conceptual and practical challenges [8,37]. } \\
\text { 5. There is still no common definition, framework, and methodology for nexus } \\
\text { research [5,8,11,31]. } \\
\text { 6. It is not fully acknowledged on the ground and lacks publicity due to } \\
\text { underrepresentation of private sectors and media in its activities [7]. } \\
\text { 7. A buzzword derived from an ambiguous meaning and strong normative resonance. } \\
\text { The usage of this term is plural, fragmented, and ambiguous in the UK natural } \\
\text { resource debates [41,42]. } \\
\text { 8. It is still an evolving concept that has remained largely in the conceptual realm [32] } \\
\text { with high-level insights [37]. }\end{array}$ \\
\hline B. & $\begin{array}{l}\text { The Application of WEF Nexus Approach } \\
\text { 1. Policy processes may lead to delays [33], slowness, and inertia [36] in the } \\
\text { policy-making process, especially in developing countries. } \\
\text { 2. It not only involves technical issues but also political issues [34], while the nexus } \\
\text { concept is often inconsistent in the politics of sustainability [39]. In addition, it is } \\
\text { mostly depoliticized, neglecting historical, social, and political treatment [43]. } \\
\text { 3. In site-specific studies, the vertical integration of local nexus issues within national } \\
\text { and global nexus issues was often missing [7] due to the complex nature of the } \\
\text { nexus [35]. } \\
\text { 4. Nexus analyses are insufficiently cross-sectoral, focusing mostly on water, which } \\
\text { assigns unequal sectoral weighting [32]. } \\
\text { 5. There are no clear boundaries to constrain the WEF nexus applications [37]. } \\
\text { 6. Some of existing models and frameworks failed to capture interconnections among } \\
\text { variables due to lack of data sharing and availability [22]. }\end{array}$ \\
\hline
\end{tabular}

C. Outcome and Impact of WEF Nexus Approaches

1. The research on the nexus influence on the decision making by stakeholders is limited [33] and continues to fall short of expectations of its research-backed benefits [44].

2. The current WEF nexus discourse fails to adequately consider the politics inherent in the WEF sector [23].

3. There is a lack of evidence from WEF nexus research that has produced an intellectual toolkit, including validated claims that showed the improvement of resource management and governance outcomes [37].

4. There is a dearth of WEF nexus adoption in national policies, programs and institutions. The gender aspects are also often overlooked in WEF nexus assessments [24].

5. Ignorance of the main democratic goal of sustainability concept through over-emphasizing resource security level at the expense of livelihoods [25].

6. Operationalizing the WEF nexus is suggested in many studies and is urgently needed to bring "nexus thinking" into "nexus doing" [38].

\section{Efforts to Narrow Gaps and Address Criticisms}

From the analysis in Sections 2 and 3, common nexus research gaps have been identified in both the frameworks and in nexus critiques and reviews. This section presents recent work that has started to address some of these gaps. 


\subsection{Narrowing Knowledge Gaps}

An overview of studies that start to address gaps is compiled in Table 4. This table distinguishes three main knowledge gaps, namely: (1) lack of WEF-related datasets and knowledge; (2) insufficient availability of applications; and (3) lack of agreement and clarity of several WEF-related issues. These are discussed in more detail.

There are several data that are still considered poorly covered or poorly available for WEF analyses. Two examples include aquifer data in water-scarce regions and consumptive water use data in the energy sector [45], which are elaborated in more detail here. The five studies in Table 4 (section A1) start to contribute to filling the first example of aquifer data. MacDonald et al. [46] employed GIS-based analysis to establish continent-wide maps of aquifer storage and potential borehole yields in Africa. By reviewing maps, data, and publications, quantitative maps of groundwater in Africa can be developed to assess water security at the national and regional levels. Lezzaik and Milewski [47] have attempted to deal with the paucity of aquifer data in middle-east and north African (MENA) regions. They estimated groundwater storage reserves based on saturated thickness and effective porosity estimates of groundwater using GIS-based models. Additionally, to measure the alteration in groundwater storage, monthly gravimetric datasets (GRACE) and land surface parameters (GLDAS) were used. Modelling approaches such as MODFLOW [48], random forest models, and maximum entropy models [49], water balance equations and water table fluctuation analysis [50] have been used to estimate aquifer yields in several water-scarce regions such Iran, Libya, Egypt, Sudan, and other African countries.

Studies on the consumptive water use in the energy sector (Table 4, section A2) are more numerous. For instance, Davies et al. [51] investigate consumptive water demand for electricity production at the global level using an integrated assessment model of energy, agriculture, and climate change (the GCAM model). Similarly, Mekonnen et al. [52] evaluate the global consumptive water footprint (WF) of electricity and heat generation in the fuel supply, construction, and operational stages. Other researchers applied similar objectives to different regions, such as in China [53] and the European Union (EU) [54]. A review paper by Dodder [55] highlighted some scenarios of future water demand in the energy sector.

Discussions on the impacts of hydropower and other water resources developments on aquatic ecosystems and full life-cycle assessments in terms of water and energy impacts have been addressed by various studies (Table 4, sections A3 and A4). The gaps addressing studies on topics A5 and A6 (Table 4) are insufficiently addressed. For example, the topic of nutritional water productivity is still very limited, although a few studies have explored the issue [52-55]. These studies contribute to narrowing knowledge gaps in the WEF nexus, especially in relation to ecosystem services (cf. [3]). Similarly, the discussion on energy productivity in agriculture (A6) has not been addressed adequately, though some studies have attempted to deal with this issue (e.g., [56-59]).

Not all studies directly address Hoff's knowledge gaps. Regarding the issue of energy productivity (A6), most studies link energy productivity with the industrial or manufacturing sectors but neglect the agricultural sector, possibly omitting an important source of energy demand and production. As another example, there is considerable research related to the water footprint of energy and food production (see B1), but not all studies use a consistent framework, thereby precluding common assessment and comparison. The availability of a harmonized database and indicators for the WEF nexus, an analytical framework that is able to monitor the potential trade-offs and synergies in WEF resource management, and WEF nexus analysis that can resolve institutional disconnects and power imbalances are the main gaps that must be prioritized to be addressed in the future nexus studies and applications. 
Table 4. Summary of research related to addressing WEF nexus knowledge gaps.

\begin{tabular}{|c|c|c|}
\hline & Hoff's Knowledge Gaps * & $\begin{array}{c}\text { Related Studies Addressing } \\
\text { the Gaps }\end{array}$ \\
\hline A. & $\begin{array}{l}\text { Lack of WEF Datasets and Knowledge on: } \\
\text { 1. the available water resources data especially on safe } \\
\text { aquifer yields in "economically water-scarce" regions } \\
\text { 2. the consumptive water use in the energy sector, } \\
\text { compared to withdrawal data } \\
\text { 3. water productivity per nutritional content of food } \\
\text { products } \\
\text { 4. energy productivity in agriculture } \\
\text { 5. the impacts of hydropower and other water resources } \\
\text { development on aquatic ecosystems } \\
\text { 6. the full life-cycle assessments in terms of water } \\
\text { and energy }\end{array}$ & $\begin{array}{l}{[46-50]} \\
{[51-55]} \\
{[56-59]} \\
{[60-64]} \\
{[65-70]} \\
{[71-75]}\end{array}$ \\
\hline B. & $\begin{array}{l}\text { Insufficient Availability of: } \\
\text { 1. the uniformly applicable "water footprint" framework } \\
\text { regarding water use efficiency for different forms of } \\
\text { energy or food production } \\
\text { 2. the harmonized "nexus database" or analytical } \\
\text { framework for monitoring or trade-off analyses } \\
\text { 3. the blueprint for overcoming institutional disconnect } \\
\text { and power imbalances between sectors }\end{array}$ & $\begin{array}{c}{[76-81]} \\
{[16,82-87]}\end{array}$ \\
\hline C. & $\begin{array}{l}\text { Lack of Agreement and Clarity on: } \\
\text { 1. the water quality standards for different crops and } \\
\text { production systems } \\
\text { 2. the impact of policy frameworks on water and energy } \\
\text { use and resource use efficiency in food production } \\
\text { 3. the impacts of increasing energy scarcity on water and } \\
\text { food security } \\
\text { 4. how to deal with the increasing level of complexity that } \\
\text { comes with higher levels of integration }\end{array}$ & {$[8,22,33,44,92,106,107]$} \\
\hline
\end{tabular}
* Adapted from Holger Hoff [6].

\subsection{Addressing Criticisms in WEF Nexus Frameworks}

Further issues are suggested that should be considered as improvements of WEF nexus research to assist planners and policy-makers. Three main issues are identified: (1) participatory stakeholder involvement in designing and carrying out nexus research; (2) a comprehensive, open-access (where possible) WEF nexus database; and (3) an updated WEF nexus framework to support policy and decision-making, including the concept of WEF resource security, which is rarely considered, although it is a central aspect [85].

The first issue regards participatory engagement of related stakeholders to raise awareness and increase the understanding of the nexus for those responsible for its planning and management (e.g., $[8,22,33,38,108])$. Sušnik et al. [83] engaged multiple stakeholders from project inception to the development of a WEF nexus serious game to understand the interaction between water, energy, food, land, and climate. Through the SIM4NEXUS project [20], which includes 12 case studies from regional to a global scale, stakeholders and local partners were involved in all nexus modelling stages, including conceptualization, quantitative model development, validation, and implementation of serious games. Using another approach, Purwanto et al. [108] implement a group model building (GMB) technique to develop qualitative causal loop diagrams of WEF nexus security in Indonesia by involving local expert stakeholders. The awareness-raising and better understanding of stakeholders about the complexity of the WEF nexus was one of the main outcomes in that process. A study on early stakeholder involvement to ensure perspective convergence among researchers and stakeholders in WEF-related sectors was conducted by Daher et al. [109] in the San Antonio Region. They provided questionnaires to 370 respondents from three different groups (i.e., government institutions, non-government/non-profit, 
and business enterprises). The main objectives were to evaluate the level of convergence of nexus understanding and to identify barriers and opportunities regarding improving communication among stakeholders. There are many studies that have applied participatory approaches in WEF research, including fuzzy-cognitive mapping, online investigation and snowball sampling [110], interviews, focus group discussions and vision-building workshops [111], and multi-objective optimization methods for WEF nexus management and the involvement of multiple stakeholders $[112,113]$. These studies demonstrate that multiple actors should work together for continuous improvements to make the nexus approach useful in the planning, evaluation, and decision-making processes. Researchers are involving key stakeholders throughout the nexus investigation process more regularly.

To make the WEF nexus concept work for quantitative assessment, valid, integrated, and open data sources at all levels and scales must be available for governments and scientific institutions. As listed in Table 4 (B2), this is crucial because current WEF nexus data availability can still pose a major challenge in the analytical process, especially at the local level [6,22]. The problem of data availability, validity, quality, and accessibility in many countries particularly in developing countries is common. Several global, regional, and country-level WEF data sources are more readily available compared with data at the local level. However, existing datasets are not comprehensive, data quality and reliability can be questionable, and data are separated from each other and not contained in a "WEF system database". Table 5 summarizes some of the sources of WEF-related data at global, regional, and country levels.

Table 5. Some water, energy, and food data sources.

\begin{tabular}{|c|c|c|}
\hline Data Source & Type of Data & Level \\
\hline \multicolumn{3}{|l|}{ Water } \\
\hline $\begin{array}{l}\text { FAO (Food and Agriculture } \\
\text { Organization)—AQUASTAT } \\
\text { (http://www.fao.org/nr/water/aquastat/data/; } \\
\text { accessed on } 2 \text { December 2020) }\end{array}$ & $\begin{array}{l}\text { Land use, economy-development-food security, precipitation, } \\
\text { renewable water resource, dam capacity, water withdrawal, } \\
\text { wastewater, irrigation and drainage, water conservation, } \\
\text { water harvesting, flood occurrence, drinking water } \\
\text { access, etc.) }\end{array}$ & $\begin{array}{l}\text { - Global } \\
\text { - Country }\end{array}$ \\
\hline $\begin{array}{l}\text { Water Footprint Network (https: } \\
\text { // waterfootprint.org/en/resources/waterstat/; } \\
\text { accessed on } 2 \text { December 2020) }\end{array}$ & $\begin{array}{l}\text { Product water footprint, national water footprint, } \\
\text { International virtual water flow, monthly gridded blue water } \\
\text { footprint, water scarcity, water pollution level, etc. }\end{array}$ & $\begin{array}{l}\text { - Global } \\
\text { - Country }\end{array}$ \\
\hline $\begin{array}{l}\text { USGS data (https: / / waterdata.usgs.gov/nwis; } \\
\text { accessed on } 2 \text { December 2020) }\end{array}$ & Surface water, groundwater, water quality, water use & $\begin{array}{l}\text { - Global } \\
\text { - Country }\end{array}$ \\
\hline $\begin{array}{l}\text { Energy } \\
\text { IEA (International Energy Agency) } \\
\text { (https:/ / www.iea.org/data-and-statistics; } \\
\text { accessed on } 2 \text { December 2020) } \\
\text { IRENA (International Renewable Energy Agency) } \\
\text { (https:/ / www.irena.org/Statistics; accessed on } \\
2 \text { December 2020) }\end{array}$ & $\begin{array}{l}\text { Energy supply, energy consumption, electricity, energy } \\
\text { import-export, } \mathrm{CO}_{2} \text { emission, energy prices, } \\
\text { renewable energy } \\
\text { Capacity and generation, energy balances, energy transition, } \\
\text { energy policy, cost, climate change, finance and investment }\end{array}$ & $\begin{array}{l}\text { - } \text { Global } \\
\text { - Regional } \\
\text { - } \text { Country } \\
\text { - Global } \\
\text { - Regional } \\
\text { - Country }\end{array}$ \\
\hline \multicolumn{3}{|l|}{ Food } \\
\hline $\begin{array}{l}\text { FAO (Food and Agriculture Organization) } \\
\text { (http://www.fao.org/faostat/en/\#data; } \\
\text { accessed on } 2 \text { December 2020) }\end{array}$ & $\begin{array}{l}\text { Food production, trade, food balance, food security, price, } \\
\text { inputs, population, investment, macro-statistics, } \\
\text { agri-environmental Indicators, emission-agriculture, } \\
\text { emission-land use, forestry, etc. }\end{array}$ & $\begin{array}{l}\text { - Global } \\
\text { - Country }\end{array}$ \\
\hline $\begin{array}{l}\text { OECD-FAO } \\
\text { (http:/ / www.agri-outlook.org/ data/; accessed } \\
\text { on } 2 \text { December 2020) }\end{array}$ & $\begin{array}{l}\text { Agricultural product, consumption, imports, dairy, meats, } \\
\text { fishery, etc. }\end{array}$ & $\begin{array}{l}\text { - } \text { Global } \\
\text { - Regional } \\
\text { - Country }\end{array}$ \\
\hline $\begin{array}{l}\text { Multiple Data } \\
\text { (http:/ / data.worldbank.org/indicator/; } \\
\text { accessed on 2 December 2020) }\end{array}$ & \multirow{2}{*}{$\begin{array}{l}\text { Data and indicators related to agricultural data, economy, } \\
\text { energy, environment, climate change, water etc. } \\
\text { Agricultural production, meat and dairy, fishery, energy, } \\
\text { access to energy, renewable energy, air pollution, clean water, } \\
\text { sanitation, etc. }\end{array}$} & $\begin{array}{l}\text { - Global } \\
\text { - Country }\end{array}$ \\
\hline $\begin{array}{l}\text { (https://ourworldindata.org/energy; accessed on } \\
2 \text { December 2020) }\end{array}$ & & $\begin{array}{l}\text { - Global } \\
\text { - Country }\end{array}$ \\
\hline
\end{tabular}


One significant effort is the development of an integrated data and analysis toolbox called NeFEW (Nexus of Food, Energy and Water) to incorporate available global datasets [87]. This toolbox gathers data to allow for modelling and analysis of WEF resources and their interconnectedness at a country level. Lawford [84] analysed the importance of integrated WEF nexus data and information to assist practitioners in planning and decision-making processes. He proposed WEFDIS (WEF nexus data and information system) to ensure that WEF data and information from satellites, in situ data networks, and other data sources are readily available. Eight proposed sequential and parallel measures to develop and implement WEFDIS and to structure WEFDIS are discussed in Lawford [84]. Accessibility and standardization of data are two important points to communicate and consolidate data and information from various sources. The incorporation of existing WEF-related databases is a good example of potential data integration and would enable replication at a smaller scale. To harmonize databases at a local level, more research appears to be needed, largely due to the diversity of data sources and formats.

On-the-ground WEF nexus implementation is the third issue. Operationalizing the WEF nexus to assist policy-makers and other stakeholders in managing resources is a main recommendation in several WEF nexus-related discussions, including Shannak et al. [22], Albrecht et al. [8], and Simpson and Jewitt [38], and is included in Hoff's knowledge gaps (Table 4, B3). The improvement of the nexus concept by transitioning towards "doing" instead of only "thinking" has been established in several studies. Studies by Purwanto et al. $[85,108]$ are examples on how to integrate the WEF nexus concept into local planning systems to assist local stakeholders in achieving WEF security targets in a regional context. Other evidence of WEF nexus implementation can be seen in Hoff et al. [114] through five case studies in MENA countries (Jordan, Lebanon, and Morocco). They evaluate the current nexus conditions and to link that to Sustainable Development Goal (SDG) ambitions and Nationally Determined Contributions (NDCs). An integrative study to assess the progress towards SDGs targets in South Africa using a WEF nexus analytical model has been conducted by Nhamo et al. [86] who applied seven WEF nexus composite indices (water availability, water productivity, energy accessibility, energy productivity, food self-sufficiency, cereal productivity, and an integrated WEF index) to evaluate SDG targets 2, 6, and 7 in the period 2015 to 2018. Further research is expected to strengthen the concept and bring the new methodologies and empirical evidence to influence policy and decision-making processes [115].

Regarding responses to criticisms of the WEF nexus approach in general, one valuable commentary comes from Brouwer et al. [115] in response to Galaitsi et al. [37]. They offer evidence from the Horizon 2020 SIM4NEXUrS project [116] that identifies the added value of the WEF nexus concept, including flexibility and adaptability, the ability to identify critical nexus-relevant policy objectives, and the better identification of trade-offs and synergies for resource management and policy-making. They contend that the nexus concept is supportive in WEF-related policy-making processes. More specifically, three key features of the nexus concept were proposed to be improved upon, namely (1) focus on bio-physical, socio-economic and policy interactions, (2) seeking a balance between different needs to achieve sustainable and integrated natural resources management, and (3) a systematic effort for policy coherence across sectors.

\section{Updating the WEF Nexus Frameworks}

Despite the progress made in addressing nexus research gaps, some areas remain unaddressed. In this section, four main issues still needing research are proposed, and these are incorporated into an updated WEF nexus framework. These issues are (Figure 3):

1. Making the nexus relevant for stakeholders and policy This underlines the importance of participatory engagement to ensure that stakeholders in the water, energy, and food sectors can understand the interlinkages in the nexus and what this means for policyand decision-making. Several methods could be used such as participatory modelling, 
group model building (cf. Purwanto et al., 2019), focus group discussions, and surveys and interviews, but the inclusion of relevant stakeholders throughout is critical.

2. The issue of reliable data and information Any WEF nexus study outputs should be based as much as possible on reliable data that are valid and integrated, and that are available with a good level of accessibility to facilitate quantitative analysis and providing robust, defensible results. Ideally, a universal, open-access, WEF database would be developed.

3. Creating an adaptable framework Framework adaptability is important in the WEF nexus due to the diversity of resources, natural conditions, scales, levels, government, and planning systems, the responsibility of institutions, laws and regulations, and key nexus foci. As such, any framework must have the flexibility to adapt to a diverse set of circumstances.

4. Being easily applicable Incorporating the WEF nexus into planning and decision-making systems is essential to move the WEF nexus from a concept to an operational framework that brings real benefits for a more sustainable and integrated policy-making process.

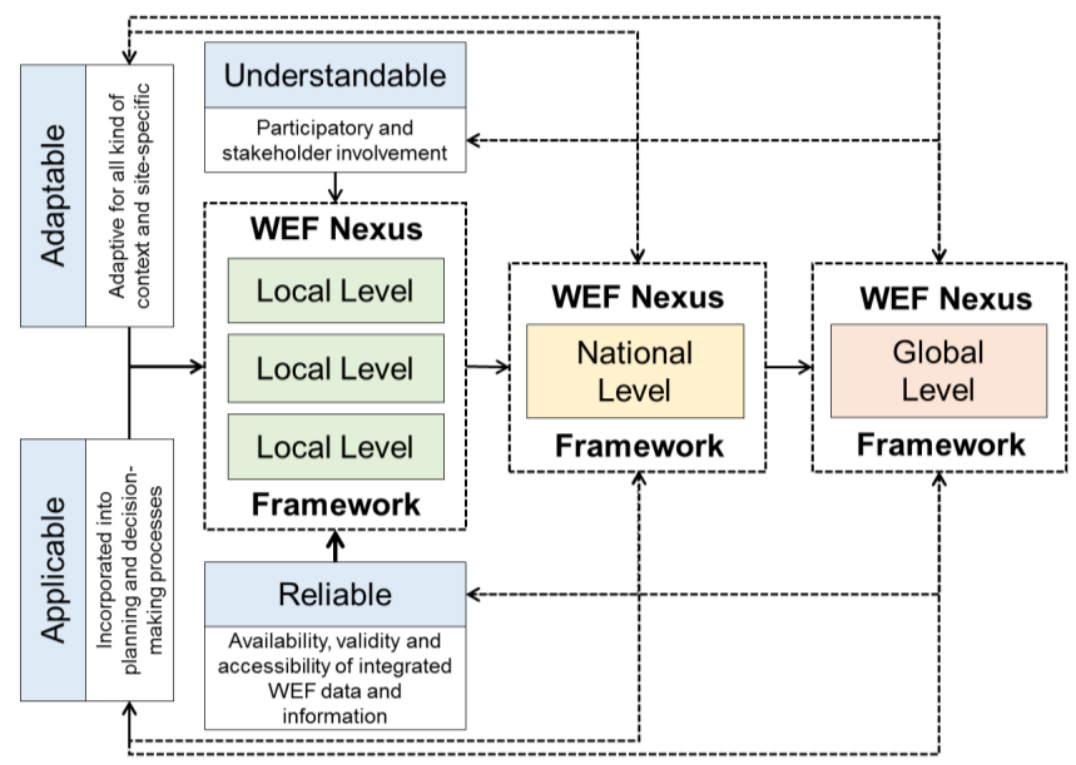

Figure 3. The main proposed principles and perspective for future WEF nexus concepts and frameworks.

To include these principles, a bottom-up "local to global" approach is proposed so that lower levels of government are able to identify WEF resource challenges and solve them through proper planning and actions, using locally relevant approaches exploiting the best available data and information. Well-achieved targets at the local level may add up to affect WEF resource security at a higher level of governance. However, the four challenges can also refer to what is done at a higher level. For example, the availability and integration of WEF datasets at the global and national levels are relatively better than at the local level. Therefore, methods to develop indices, parameters, and individual datasets can be adopted from global and national sources for local scales, thereby potentially improving multi-scale nexus assessment and relevance.

\section{Conclusions}

This paper has investigated knowledge gaps, criticisms, and areas for improvement related to research on the WEF nexus that have emerged since the concept of WEF (security) nexus was proposed. Thirteen knowledge gaps were identified by Hoff [6]. During the last decade, a number of efforts have been made to narrow these gaps. In this study, 67 papers are reviewed that consider Hoff's gaps. Despite significant progress, some gaps have not been entirely filled, such as those related to energy productivity in agriculture, 
harmonizing a WEF nexus database, and the relevance of WEF resource security. Critiques on the concept, application, and operationalisation of the WEF nexus approach have been considered in this study.

Furthermore, ten WEF nexus frameworks have been analysed and compared with sixteen suggested features for WEF nexus inclusion. The following issues are insufficiently addressed in existing frameworks: the WEF security focus (resource availability, accessibility, and quality); robust systems approach and datasets; participatory stakeholder engagement in nexus research. Additionally, a general lack of the importance of ecosystems and their services is prevalent. Local perspectives are often under-represented, especially in developing countries with decentralized governance systems. Context-specific practical and policy implementation guidance in evaluation and planning still needs to be improved. It is suggested that locally based WEF management will help ensure that WEF resources are managed in a holistic and equitable way. The WEF nexus approach should move from thinking to doing, starting from the lowest level (i.e., moving from conceptual ideas to practical and relevant applications). Stakeholder participation is crucial to manage WEF resources. At the same time, it is critical to prevent delays in the process of decision-making that can be caused by ineffectiveness of time allocation to accommodate the various kinds of stakeholder's interests.

Four principles and perspectives for future WEF nexus framework development (i.e., to make them more understandable, to ensure reliable and valid data, to make them adaptable to many diverse situations, and to be applicable across scales) are considered central to increasing the benefits and improving the role of the WEF nexus concept in influencing policy and resource planning processes. Continuous improvements, especially in grounding the WEF nexus concept, indicate the urgent challenge to better manage the three resources of water, energy and food.

Author Contributions: Conceptualization, A.P., J.S., F.X.S., and C.d.F.; formal analysis, A.P., J.S.; writing—original draft preparation, A.P., J.S., writing—review and editing, A.P., J.S., F.X.S., and C.d.F. All authors have read and agreed to the published version of the manuscript.

Funding: This research was supported by Indonesia Endowment Fund for Education (LPDP), Ministry of Finance of Indonesia (contract number: 20160222015544/LPDP/2016).

Institutional Review Board Statement: Not applicable.

Informed Consent Statement: Not applicable.

Data Availability Statement: All papers cited are available on platforms such as ScienceDirect. No specific data were used in this study.

Acknowledgments: The authors gratefully acknowledge all the supports from the editor(s) and reviewers to improve the quality of the article. The first author would like also to thank the Indonesia Endowment Fund for Education (LPDP), Ministry of Finance of Indonesia for its financial support. We acknowledge three anonymous reviewers for their constructive comments in improving the quality of this manuscript.

Conflicts of Interest: The authors declare no conflict of interest.

\section{References}

1. de Fraiture, C.; Molden, D.; Wichelns, D. Investing in water for food, ecosystems, and livelihoods: An overview of the comprehensive assessment of water management in agriculture. Agric. Water Manag. 2010, 97, 495-501. [CrossRef]

2. Sušnik, J. Data-driven quantification of the global water-energy-food system. Resour. Conserv. Recycl. 2018, 133, 179-190. [CrossRef]

3. Hülsmann, S.; Sušnik, J.; Rinke, K.; Langan, S.; van Wijk, D.; Janssen, A.B.G.; Mooij, W.M. Integrated modelling of water resources: The ecosystem perspective on the nexus approach. Curr. Opin. Environ. Sustain. 2019, 40, 14-20. [CrossRef]

4. Bizikova, L.; Roy, D.; Swanson, D.; Venema, H.D.; McCandless, M. The Water-Energy-Food Security Nexus: Towards a Practical Planning and Decision-Support Framework for Landscape Investment and Risk Management; International Institute for Sustainable Development (IISD): Winnipeg, MB, Canada, 2013.

5. Endo, A.; Burnett, K.; Orencio, P.M.; Kumazawa, T.; Wada, C.A.; Ishii, A.; Tsurita, I.; Taniguchi, M. Methods of the water-energyfood nexus. Water 2015, 7, 5806-5830. [CrossRef] 
6. Hoff, H. Understanding the nexus. In Proceedings of the Background Paper for the Bonn2011 Conference: The Water, Energy and Food Security Nexus, Stockholm, Sweden, 16-18 November 2011.

7. Endo, A.; Tsurita, I.; Burnett, K.; Orencio, P.M. A review of the current state of research on the water, energy, and food nexus. J. Hydrol. Reg. Stud. 2017, 11, 20-30. [CrossRef]

8. Albrecht, T.R.; Crootof, A.; Scott, C.A. The water-energy-food nexus: A systematic review of methods for nexus assessment. Environ. Res. Lett. 2018, 13, 1-26. [CrossRef]

9. WEF. Global Risks 2011 Six Edition: An Initiative of the Risk Response Network; World Economic Forum: Geneva, Switzerland, 2011.

10. Walters, W.H. Citation-Based Journal Rankings: Key Questions, Metrics, and Data Sources. IEEE Access 2017, 5, $22036-22053$. [CrossRef]

11. Benson, D.; Gain, A.K.; Rouillard, J.J. Water governance in a comparative perspective: From IWRM to a 'nexus' approach? Water Altern. 2015, 8, 756-773.

12. Bell, A.; Matthews, N.; Zhang, W. Opportunities for Improved Promotion of Ecosystem Services in Agriculture under the Water-Energy-Food Nexus. J. Environ. Stud. Sci. 2016, 6, 183-191. [CrossRef]

13. ICIMOD. Contribution of Himalayan Ecosystems to Water, Energy and Food Security in South Asia: A Nexus Approach; ICIMOD: Kathmandu, Nepal, 2012.

14. European Report on Development. Confronting Scarcity: Managing Water, Energy and Land for Inclusive and Sustainable Growth; European Union: Brussels, Belgium, 2012.

15. Andrews-Speed, P.; Bleischwitz, R.; Boersma, T.; Johnson, C.; Kemp, G.; VanDeveer, S.D. The Global Resource Nexus: The Struggles for Land, Energy, Food, Water, and Minerals; The Transatlantic Academy: Washington, DC, USA, 2012.

16. Howells, M.; Hermann, S.; Welsch, M.; Bazilian, M.; Segerstrom, R.; Alfstad, T.; Rogner, H.; Fischer, G.; van Velthuizen, H.; Wiberg, D.; et al. Integrated analysis of climate change, land-use, energy and water strategies. Nat. Clim. Chang. 2013, 3, 621-626. [CrossRef]

17. UNECE. Reconciling Resource Uses in Transboundary Basins: Assessment of the Water-Food-Energy-Ecosystems Nexus; United Nations: Geneva, Switzerland, 2015.

18. Flammini, A.; Puri, M.; Pluschke, L.; Dubois, O. Walking the Nexus Talk: Assessing the Water-Energy-Food Nexus in the Context of the Sustainable Energy for All Initiative; Food and Agriculture Organization (FAO): Rome, Italy, 2014.

19. Bellfield, H.; Leggett, M.; Trivedi, M.; Pareira, J.; Gangga, A. How Can Indonesia Achieve Water, Energy and Food Security without Eroding its Natural Capital? WCS Indonesia and Global Canopy Programme: Jakarta, Indonesia, 2016.

20. Ramos, E.; Kofinas, D.; Papadopoulou, C.; Papadopoulou, M.; Gardumi, F.; Brouwer, F.; Fournier, M.; Lluis, E.; Domingo, X.; Vamvakeridou-Lyroudia, L.; et al. D1.5: Framework for the Assessment of the Nexus. SIM4NEXUS. 2020. Available online: www.sim4nexus.eu (accessed on 15 January 2021).

21. OECD. The Land-Water-Energy Nexus: Biophysical and Economic Consequences; OECD Publishing: Paris, France, 2017.

22. Shannak, S.; Mabrey, D.; Vittorio, M. Moving from theory to practice in the water-energy-food nexus: An evaluation of existing models and frameworks. Water-Energy Nexus 2018, 1, 17-25. [CrossRef]

23. de Grenade, R.; House-Peters, L.; Scott, C.A.; Thapa, B.; Mills-Novoa, M.; Gerlak, A.; Verbist, K. The nexus: Reconsidering environmental security and adaptive capacity. Curr. Opin. Environ. Sustain. 2016, 21, 15-21. [CrossRef]

24. FAO. Accelerating SDG 7 Achievement; Policy Brief 09; Water-Energy-Food Nexus for the review of SDG 7; FAO: Rome, Italy, 2018.

25. Biggs, E.M.; Bruce, E.; Boruff, B.; Duncan, J.M.A.; Horsley, J.; Pauli, N.; McNeill, K.; Neef, A.; van Ogtrop, F.; Curnow, J.; et al. Sustainable development and the water-energy-food nexus: A perspective on livelihoods. Environ. Sci. Policy 2015, 54, 389-397. [CrossRef]

26. Bazilian, M.; Rogner, H.; Howells, M.; Hermann, S.; Arent, D.; Gielen, D.; Steduto, P.; Mueller, A.; Komor, P.; Tol, R.S.J.; et al. Considering the Energy, Water and Food Nexus: Towards an Integrated Modelling Approach. Energy Policy 2011, 39, 7896-7906. [CrossRef]

27. Keairns, D.L.; Darton, R.C.; Irabien, A. The Energy-Water-Food Nexus. Annu. Rev. Chem. Biomol. Eng. 2016, 7, 239-262. [CrossRef]

28. Urbinatti, A.M.; Benites-Lazaro, L.L.; de Carvalho, C.M.; Giatti, L.L. The conceptual basis of water-energy-food nexus governance: Systematic literature review using network and discourse analysis. J. Integr. Environ. Sci. 2020, 17, 21-43. [CrossRef]

29. Endo, A.; Yamada, M.; Miyashita, Y.; Sugimoto, R.; Ishii, A.; Nishijima, J.; Fujii, M.; Kato, T.; Hamamoto, H.; Kimura, M.; et al. Dynamics of water-energy-food nexus methodology, methods, and tools. Curr. Opin. Environ. Sci. Health 2019, 13, 46-60. [CrossRef]

30. Taniguchi, M.; Endo, A.; Gurdak, J.J.; Swarzenski, P. Water-Energy-Food Nexus in the Asia-Pacific Region. J. Hydrol. Reg. Stud. 2017, 11, 1-8. [CrossRef]

31. Dai, J.; Wu, S.; Han, G.; Weinberg, J.; Xie, X.; Wu, X.; Song, X.; Jia, B.; Xue, W.; Yang, Q. Water-energy nexus: A review of methods and tools for macro-assessment. Appl. Energy 2018, 210, 393-408. [CrossRef]

32. Smajgl, A.; Ward, J.; Pluschke, L. The water-food-energy Nexus-Realising a new paradigm. J. Hydrol. 2016, 533, 533-540. [CrossRef]

33. Wichelns, D. The water-energy-food nexus: Is the increasing attention warranted, from either a research or policy perspective? Environ. Sci. Policy 2017, 69, 113-123. [CrossRef]

34. Middleton, C.; Allouche, J.; Gyawali, D.; Allen, S. The rise and implications of the water-energy-food nexus in Southeast Asia through an environmental justice lens. Water Altern. 2015, 8, 627-654. 
35. Allouche, J.; Middleton, C.; Gyawal, D. Nexus Nirvana or Nexus Nullity? A Dynamic Approach to Security and Sustainability in the Water-Energy-Food Nexus; STEPS Working Paper 63; STEPS Centre: Brighton, UK, 2014.

36. Mitchell, B.; Bellette, K.; Richardson, S. 'Integrated' approaches to water and natural resources management in South Australia. Int. J. Water Resour. Dev. 2015, 31, 718-731. [CrossRef]

37. Galaitsi, S.; Veysey, J.; Huber-lee, A. Where Is the Added Value? A Review of the Water-Energy-Food Nexus Literature; Stockholm Environment Institute: Stockholm, Sweden, 2018.

38. Simpson, G.B.; Jewitt, G.P. The water-energy-food nexus in the anthropocene: Moving from 'nexus thinking' to 'nexus action'. Curr. Opin. Environ. Sustain. 2019, 40, 117-123. [CrossRef]

39. Leese, M.; Meisch, S. Securitising sustainability? Questioning the 'water, energy and food-security nexus. Water Altern. 2015, 8, 695-709.

40. Reinhard, S.; Verhagen, J.; Wolters, W.; Ruben, R. Water-Food-Energy Nexus; Wageningen Economic Research: Wageningen, The Netherlands, 2017; p. 28.

41. Leck, H.; Conway, D.; Bradshaw, M.; Rees, J. Tracing the water-energy-food nexus: Description, theory and practice. Geogr. Compass 2015, 9, 445-460. [CrossRef]

42. Cairns, R.; Krzywoszynska, A. Anatomy of a buzzword: The emergence of 'the water-energy-food nexus' in UK natural resource debates. Environ. Sci. Policy 2016, 64, 164-170. [CrossRef]

43. Foran, T. Node and regime: Interdisciplinary analysis of water-energy-food nexus in the Mekong region. Water Altern. 2015, 8, 655-674.

44. Dargin, J.; Daher, B.; Mohtar, R.H. Complexity versus simplicity in water energy food nexus (WEF) assessment tools. Sci. Total Environ. 2019, 650, 1566-1575. [CrossRef]

45. Macknick, J.; Newmark, R.; Heath, G.; Hallett, K.C. Operational water consumption and withdrawal factors for electricity generating technologies: A review of existing literature. Environ. Res. Lett. 2012, 7, 045802. [CrossRef]

46. MacDonald, A.M.; Bonsor, H.C.; Dochartaigh, B.É.Ó.; Taylor, R.G. Quantitative maps of groundwater resources in Africa. Environ. Res. Lett. 2012, 7, 024009. [CrossRef]

47. Lezzaik, K.; Milewski, A. A quantitative assessment of groundwater resources in the Middle East and North Africa region. Hydrogeol. J. 2018, 26, 251-266. [CrossRef]

48. van Camp, M.; Mjemah, I.C.; al Farrah, N.; Walraevens, K. Modeling approaches and strategies for data-scarce aquifers: Example of the Dar es Salaam aquifer in Tanzania. Hydrogeol. J. 2013, 21, 341-356. [CrossRef]

49. Rahmati, O.; Pourghasemi, H.R.; Melesse, A.M. Application of GIS-based data driven random forest and maximum entropy models for groundwater potential mapping: A case study at Mehran Region, Iran. Catena 2016, 137, 360-372. [CrossRef]

50. Rezaei, A.; Mohammadi, Z. Annual safe groundwater yield in a semiarid basin using combination of water balance equation and water table fluctuation. J. Afr. Earth Sci. 2017, 134, 241-248. [CrossRef]

51. Davies, E.G.R.; Kyle, P.; Edmonds, J.A. An integrated assessment of global and regional water demands for electricity generation to 2095. Adv. Water Resour. 2013, 52, 296-313. [CrossRef]

52. Mekonnen, M.M.; Gerbens-Leenes, P.W.; Hoekstra, A.Y. The consumptive water footprint of electricity and heat: A global assessment. Environ. Sci. Water Res. Technol. 2015, 1, 285-297. [CrossRef]

53. Liao, X.; Hall, J.W.; Eyre, N. Water use in China's thermoelectric power sector. Glob. Environ. Chang. 2016, 41, 142-152. [CrossRef]

54. Vanham, D.; Medarac, H.; Schyns, J.F.; Hogeboom, R.J.; Magagna, D. The consumptive water footprint of the European union energy sector. Environ. Res. Lett. 2019, 14, 104016. [CrossRef]

55. Dodder, R.S. A review of water use in the U.S. electric power sector: Insights from systems-level perspectives. Curr. Opin. Chem. Eng. 2014, 5, 7-14. [CrossRef]

56. Nyathi, M.K.; Annandale, J.G.; Beletse, Y.G.; Beukes, D.J.; Plooy, C.P.d.; Pretorius, B.; van Halsema, G.E. Nutritional Water Productivity of Traditional Vegetable Crops; Water Research Commission: Gezina, South Africa, 2016.

57. Nyathi, M.K.; van Halsema, G.E.; Beletse, Y.G.; Annandale, J.G.; Struik, P.C. Nutritional water productivity of selected leafy vegetables. Agric. Water Manag. 2018, 209, 111-122. [CrossRef]

58. Nyathi, M.K.; Mabhaudhi, T.; van Halsema, G.E.; Annandale, J.G.; Struik, P.C. Benchmarking nutritional water productivity of twenty vegetables-A review. Agric. Water Manag. 2019, 221, 248-259. [CrossRef]

59. Nouri, H.; Stokvis, B.; Borujeni, S.C.; Galindo, A.; Brugnach, M.; Blatchford, M.L.; Alaghmand, S.; Hoekstra, A.Y. Reduce blue water scarcity and increase nutritional and economic water productivity through changing the cropping pattern in a catchment. J. Hydrol. 2020, 588, 125086. [CrossRef]

60. Ball, V.E.; Färe, R.; Grosskopf, S.; Margaritis, D. The role of energy productivity in U.S. agriculture. Energy Econ. 2015, 49, 460-471. [CrossRef]

61. Moghaddasi, R.; Pour, A.A. Energy consumption and total factor productivity growth in Iranian agriculture. Energy Rep. 2016, 2, 218-220. [CrossRef]

62. Elsoragaby, S.; Yahya, A.; Mahadi, M.R.; Nawi, N.M.; Mairghany, M. Energy utilization in major crop cultivation. Energy 2019, 173, 1285-1303. [CrossRef]

63. Rautaray, S.K.; Pradhan, S.; Mohanty, S.; Dubey, R.; Raychaudhuri, S.; Mohanty, R.K.; Mishra, A.; Ambast, S.K. Energy efficiency, productivity and profitability of rice farming using Sesbania as green manure-cum-cover crop. Nutr. Cycl. Agroecosyst. 2020, 116, 83-101. [CrossRef] 
64. Pan, S.-Y.; Snyder, S.W.; Packman, A.I.; Lin, Y.J.; Chiang, P.-C. Cooling water use in thermoelectric power generation and its associated challenges for addressing water-energy nexus. Water-Energy Nexus 2018, 1, 26-41. [CrossRef]

65. Liermann, C.R.; Nilsson, C.; Robertson, J.; Ng, R.Y. Implications of dam obstruction for global freshwater fish diversity. Bioscience 2012, 62, 539-548. [CrossRef]

66. Odiyo, J.O.; Chimuka, L.; Mamali, M.A.; Fatoki, O.S. Trophic status of Vondo and Albasini Dams; impacts on aquatic ecosystems and drinking water. Int. J. Environ. Sci. Technol. 2012, 9, 203-218. [CrossRef]

67. Elosegi, A.; Sabater, S. Effects of hydromorphological impacts on river ecosystem functioning: A review and suggestions for assessing ecological impacts. Hydrobiologia 2013, 712, 129-143. [CrossRef]

68. Yan, Q.; Bi, Y.; Deng, Y.; He, Z.; Wu, L.; van Nostrand, J.D.; Shi, Z.; Li, J.; Wang, X.; Hu, Z.; et al. Impacts of the Three Gorges Dam on microbial structure and potential function. Sci. Rep. 2015, 5, 1-9. [CrossRef]

69. Fan, H.; He, D.; Wang, H. Environmental consequences of damming the mainstream lancang-mekong river: A review. Earth-Sci. Rev. 2015, 146, 77-91. [CrossRef]

70. Hecht, J.S.; Lacombe, G.; Arias, M.E.; Dang, T.D.; Piman, T. Hydropower dams of the Mekong River basin: A review of their hydrological impacts. J. Hydrol. 2019, 568, 285-300. [CrossRef]

71. Feng, K.; Hubacek, K.; Siu, Y.L.; Li, X. The energy and water nexus in Chinese electricity production: A hybrid life cycle analysis. Renew. Sustain. Energy Rev. 2014, 39, 342-355. [CrossRef]

72. Al-Ansari, T.; Korre, A.; Nie, Z.; Shah, N. Development of a life cycle assessment tool for the assessment of food production systems within the energy, water and food nexus. Sustain. Prod. Consum. 2015, 2, 52-66. [CrossRef]

73. Pacetti, T.; Lombardi, L.; Federici, G. Water-energy Nexus: A case of biogas production from energy crops evaluated by Water Footprint and Life Cycle Assessment (LCA) methods. J. Clean. Prod. 2015, 101, 278-291. [CrossRef]

74. Mannan, M.; Al-Ansari, T.; Mackey, H.R.; Al-Ghamdi, S.G. Quantifying the energy, water and food nexus: A review of the latest developments based on life-cycle assessment. J. Clean. Prod. 2018, 193, 300-314. [CrossRef]

75. Masella, P.; Galasso, I. A comparative cradle-to-gate life cycle study of bio-energy feedstock from camelina Sativa, an Italian case study. Sustainability 2020, 12, 9590. [CrossRef]

76. Okadera, T.; Geng, Y.; Fujita, T.; Dong, H.; Liu, Z.; Yoshida, N.; Kanazawa, T. Evaluating the water footprint of the energy supply of Liaoning Province, China: A regional input-output analysis approach. Energy Policy 2015, 78, 148-157. [CrossRef]

77. Wang, Y.B.; Wu, P.T.; Engel, B.A.; Sun, S.K. Application of water footprint combined with a unified virtual crop pattern to evaluate crop water productivity in grain production in China. Sci. Total Environ. 2014, 497-498, 1-9. [CrossRef]

78. Hoekstra, A.Y. Water Footprint Assessment: Evolvement of a New Research Field. Water Resour. Manag. 2017, 31, 3061-3081. [CrossRef]

79. Ababaei, B.; Etedali, H.R. Water footprint assessment of main cereals in Iran. Agric. Water Manag. 2017, 179, 401-411. [CrossRef]

80. Das, K.; Gerbens-leenes, P.W.; Nonhebel, S. The water footprint of food and cooking fuel: A case study of self- suf fi cient rural India. J. Clean. Prod. 2020, 281, 125255. [CrossRef]

81. Zhai, Y.; Zhang, T.; Bai, Y.; Ji, C.; Ma, X.; Shen, X.; Hong, J. Energy and water footprints of cereal production in China. Resour. Conserv. Recycl. 2021, 164, 105150. [CrossRef]

82. McCarl, B.A.; Yang, Y.; Srinivasan, R.; Pistikopoulos, E.N.; Mohtar, R.H. Data for WEF Nexus Analysis: A Review of Issues. Curr. Sustain. Energy Rep. 2017, 4, 137-143. [CrossRef]

83. Sušnik, J.; Chew, C.; Domingo, X.; Mereu, S.; Trabucco, A.; Evans, B.; Vamvakeridou-Lyroudia, L.; Savić, D.A.; Laspidou, C.; Brouwer, F. Multi-stakeholder development of a serious game to explore the water-energy-food-land-climate nexus: The SIM4NEXUS approach. Water 2018, 10, 139. [CrossRef]

84. Lawford, R.G. A design for a data and information service to address the knowledge needs of the Water-Energy-Food (W-E-F) Nexus and strategies to facilitate its implementation. Front. Environ. Sci. 2019, 7. [CrossRef]

85. Purwanto, A.; Sušnik, J.; Suryadi, F.X.; de Fraiture, C. Quantitative simulation of the water-energy-food (WEF) security nexus in a local planning context in indonesia. Sustain. Prod. Consum. 2020, 25, 198-216. [CrossRef]

86. Nhamo, L.; Mabhaudhi, T.; Mpandeli, S.; Dickens, C.; Nhemachena, C.; Senzanje, A.; Dhesigen, D.; Liphadzi, S.; Modi, A.T. An integrative analytical model for the water-energy-food nexus: South Africa case study. Environ. Sci. Policy 2020, 109, 15-24. [CrossRef]

87. Sadegh, M.; AghaKouchak, A.; Mallakpour, I.; Huning, L.S.; Mazdiyasni, O.; Niknejad, M.; Foufoula-Georgiou, E.; Moore, F.C.; Brouwer, J.; Farid, A.; et al. Data and analysis toolbox for modeling the nexus of food, energy, and water. Sustain. Cities Soc. 2020, 61, 102281. [CrossRef]

88. Villamayor-Tomas, S.; Grundmann, P.; Epstein, G.; Evans, T.; Kimmich, C. The water-energy-food security nexus through the lenses of the value chain and the institutional analysis and development frameworks. Water Altern. 2015, 8, 735-755.

89. Artioli, F.; Acuto, M.; McArthur, J. The water-energy-food nexus: An integration agenda and implications for urban governance. Polit. Geogr. 2017, 61, 215-223. [CrossRef]

90. Weitz, N.; Huber-Lee, A.; Nilsson, M.; Davis, M.; Hoff, H. Cross-Sectoral Integration in the Sustainable Development Goals: A Nexus Approach; Stockholm Environment Institute: Stockholm, Sweden, 2014; p. 8.

91. Märker, C.; Venghaus, S.; Hake, J.F. Integrated governance for the food-energy-water nexus-The scope of action for institutional change. Renew. Sustain. Energy Rev. 2018, 97, 290-300. [CrossRef] 
92. Mercure, J.F.; Paim, M.A.; Bocquillon, P.; Lindner, S.; Salas, P.; Martinelli, P.; Berchin, I.I.; de Andrade Guerra, J.B.S.O.; Derani, C.; de Albuquerque Junior, C.L.; et al. System complexity and policy integration challenges: The Brazilian Energy-Water-Food Nexus. Renew. Sustain. Energy Rev. 2019, 105, 230-243. [CrossRef]

93. Pahl-Wostl, C. Governance of the water-energy-food security nexus: A multi-level coordination challenge. Environ. Sci. Policy 2019, 92, 356-367. [CrossRef]

94. Bréthaut, C.; Gallagher, L.; Dalton, J.; Allouche, J. Power dynamics and integration in the water-energy-food nexus: Learning lessons for transdisciplinary research in Cambodia. Environ. Sci. Policy 2019, 94, 153-162. [CrossRef]

95. Hooda, P.S.; Edwards, A.C.; Anderson, H.A.; Miller, A. A review of water quality concerns in livestock farming areas. Sci. Total Environ. 2000, 250, 143-167. [CrossRef]

96. Love, B.J.; Nejadhashemi, A.P. Water quality impact assessment of large-scale biofuel crops expansion in agricultural regions of Michigan. Biomass Bioenergy 2011, 35, 2200-2216. [CrossRef]

97. Allende, A.; Monaghan, J. Irrigation water quality for leafy crops: A perspective of risks and potential solutions. Int. J. Environ. Res. Public Health 2015, 12, 7457-7477. [CrossRef]

98. Chalar, G.; Garcia-Pesenti, P.; Silva-Pablo, M.; Perdomo, C.; Olivero, V.; Arocena, R. Weighting the impacts to stream water quality in small basins devoted to forage crops, dairy and beef cow production. Limnologica 2017, 65, 76-84. [CrossRef]

99. Ringler, C.; Bhaduri, A.; Lawford, R. The nexus across water, energy, land and food (WELF): Potential for improved resource use efficiency? Curr. Opin. Environ. Sustain. 2013, 5, 617-624. [CrossRef]

100. Karnib, A. Bridging Science and Policy in Water-Energy-Food Nexus: Using the Q-Nexus Model for Informing Policy Making. Water Resour. Manag. 2018, 32, 4895-4909. [CrossRef]

101. van Gevelt, T. The water-energy-food nexus: Bridging the science-policy divide. Curr. Opin. Environ. Sci. Health 2020, 13, 6-10. [CrossRef]

102. Wu, L.; Elshorbagy, A.; Pande, S.; Zhuo, L. Trade-offs and synergies in the water-energy-food nexus: The case of Saskatchewan, Canada. Resour. Conserv. Recycl. 2021, 164, 105192. [CrossRef]

103. Ahmad, A.; Khan, S. Water and Energy Scarcity for Agriculture: Is Irrigation Modernization the Answer? Irrig. Drain. 2017, 66, 34-44. [CrossRef]

104. Dinar, A.; Tieu, A.; Huynh, H. Water scarcity impacts on global food production. Glob. Food Sec. 2019, 23, 212-226. [CrossRef]

105. Liu, Y.; Chen, B. Water-energy scarcity nexus risk in the national trade system based on multiregional input-output and network environ analyses. Appl. Energy 2020, 268, 114974. [CrossRef]

106. Altamirano, M.A.; van Bodegom, A.J.; van der Linden, N.; de Rijke, H.; Verhagen, J.; Bucx, T.; Boccalon, A.; van der Zwaan, B. Operationalizing the WEF Nexus Quantifying the Trade-Offs and Synergies between the Water-Energy and Food Sectors; ECN: Amsterdam, The Netherlands, 2018.

107. Sperling, J.B.; Berke, P.R. Urban Nexus Science for Future Cities: Focus on the Energy-Water-Food-X Nexus; Texas A\&M University: College Station, TX, USA, 2017.

108. Purwanto, A.; Sušnik, J.; Suryadi, F.X.; de Fraiture, C. Using group model building to develop a causal loop mapping of the water-energy-food security nexus in Karawang Regency, Indonesia. J. Clean. Prod. 2019, 240, 118170. [CrossRef]

109. Daher, B.; Hannibal, B.; Mohtar, R.H.; Portney, K. Toward understanding the convergence of researcher and stakeholder perspectives related to water-energy-food (WEF) challenges: The case of San Antonio, Texas. Environ. Sci. Policy 2020, 104, 20-35. [CrossRef]

110. Martinez, P.; Blanco, M.; Castro-Campos, B. The Water-Energy-Food Nexus: A Fuzzy-Cognitive Mapping Approach to Support Nexus-Compliant Policies in Andalusia (Spain). Water 2018, 10, 664. [CrossRef]

111. Mguni, P.; van Vliet, B.; Spaargaren, G.; Nakirya, D.; Osuret, J.; Isunju, J.B.; Ssekamatte, T.; Mugambe, R. What could go wrong with cooking? Exploring vulnerability at the water, energy and food Nexus in Kampala through a social practices lens. Glob. Environ. Chang. 2020, 63, 102086. [CrossRef]

112. Cansino-loeza, B.; Ponce-ortega, M. Sustainable Assessment of Water-Energy-Food Nexus at Regional Level through a MultiStakeholder Optimization Approach. J. Clean. Prod. 2020, 290, 125194. [CrossRef]

113. Liu, J.; Yang, H.; Cudennec, C.; Gain, A.K.; Hoff, H.; Lawford, R.; Qi, J.; de Strasser, L.; Yillia, P.T.; Zheng, C. Challenges in operationalizing the water-energy-food nexus. Hydrol. Sci. J. 2017, 62, 1714-1720. [CrossRef]

114. Hoff, H.; Alrahaife, S.A.; el Hajj, R.; Lohr, K.; Mengoub, F.E.; Farajalla, N.; Fritzsche, K.; Jobbins, G.; Özerol, G.; Schultz, R.; et al. A nexus approach for the MENA region-from concept to knowledge to action. Front. Environ. Sci. 2019, 7, 48. [CrossRef]

115. Brouwer, F.; Anzaldi, G.; Laspidou, C.; Munaretto, S.; Schmidt, G.; Strosser, P.; Sušnik, J.; Vamvakeridou-Lyroudia, L. Commentary to SEI Report 'Where is the Added Value? A Review of the Water-Energy-Food Nexus Literature'. SIM4NEXUS. 2018. Available online: www.sim4nexus.eu (accessed on 4 December 2020).

116. Sustainable Integrated Management for the NEXUS of Water-Landfood-Energy-Climate for a Resource-Efficient Europe (SIM4NEXUS). Available online: https:/ / www.sim4nexus.eu/ (accessed on 4 December 2020). 